\title{
Cytotoxicity Study of Ethanol Extract of the Leaves of Asam Kandis (Garcinia cowa Roxb.) on T47D Breast Cancer Cell line
}

\author{
Fatma Sri Wahyuni*, Dini Hara Triastuti and Helmi Arifin \\ Department of Pharmacy, Faculty of Pharmacy, Andalas University, Kampus Limau Manis, Padang, Indonesia.
}

\begin{abstract}
Objective: To investigate the cytotoxic effect of ethanolic extract of the leaves of asam kandis (Garcinia cowa Roxb.) against T47D breast cancer cells. Methods: The cytotoxicity of ethanol extract was carried out by measuring the activity of mitochondrial dehydrogenase in living cells that have ability to convert dissolved MTT pale yellow to purple formazan product. The extract was added at various concentrations $(0.1,1,10$ and $100 \mu \mathrm{g} /$ $\mathrm{mL}$ ). The level of cytotoxicity was determined by calculating the $\mathrm{IC}_{50}$ value that was based on the percentage of the cell death after 24 hours treatment with the extract. Cell morphological changes were observed by using inverted microscope. Results: The I $\mathrm{I}_{50}$ value showed that ethanol extract of leaves of asam kandis could resist T47D breast cancer cells with $I_{50}$ $6.13 \pm 3.51 \mu \mathrm{g} / \mathrm{mL}$. The statistic results proved that ethanol extract of the leaves of asam kandis could inhibit the growth of T47D breast cancer cells significantly at concentrations of $10 \mu \mathrm{g} / \mathrm{mL}$ and $100 \mu \mathrm{g} / \mathrm{mL}$. Conclusion: The results suggest that ethanol extract of the leaves of asam kandis was potential source of herbal medicine for cancer-related ailments.
\end{abstract}

Key words: Asam kandis, Beast cancer, Cytotoxicity, Garcinia cowa Roxb, MTT Assay, T47D.

\section{SUMMARY}

- The $\mathrm{IC}_{50}$ value of the ethanolic extract of the leaves of asam kandis (Garcinia cowa Roxb) is $6.13 \pm 3.51 \mu \mathrm{g} / \mathrm{ml}$ towards T47D breast cancer cell line. The results suggested that ethanol extract of the leaves of $G$. cowa was potential source of herbal medicine for cancer-related ailments.

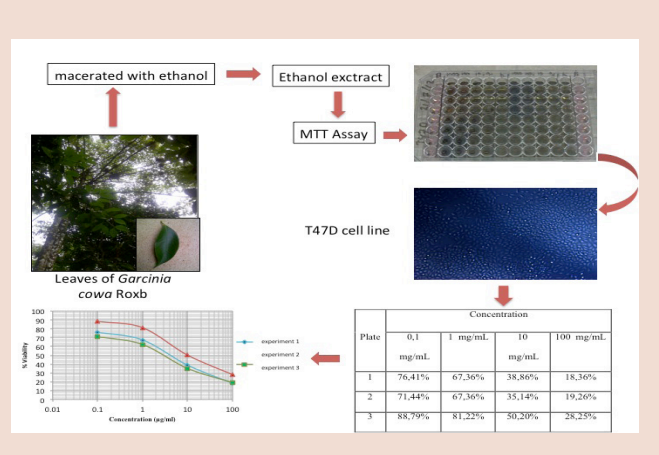

PICTORIAL ABSTRACT

Abbreviations used: MTT: [3-(4,5-dimethylthiazol-2-yl)-2,5-diphenyltetrazolium bromide], IC: Inhibition of Concentration.

\section{Correspondence:}

Mrs. Fatma Sri Wahyuni, Department of Pharmacy, Faculty Pharmacy, Andalas University, Padang-25163, Indonesia.

Phone no: +6275171682 Fax no: +62751777057

Email: fatmasriwahyuni@gmail.com

DOI : 10.5530/pj.2015.6.9

\section{INTRODUCTION}

Plants have beneficial activity in different type of diseases producing in human beings. About $80 \%$ of the world's populations still use the medicinal plants for their primary health care. ${ }^{1}$ Many pharmaceutical drug discoveries originated from traditional folk medicine and its associated plant materials and bioactive secondary metabolites.

Garcinia (Family Guttiferae) is a large genus of polygamous trees or shrubs distributed in tropical Asia, Africa, and Polynesia. Garcinia cowa Roxb., known asam kandis is a medium-sized tree with edible fruit which attains a height of about $30 \mathrm{~m}$. Traditionally, asam kandis has been used by Minang tribes for many purposes. The dry fruit of kandis is used as seasoning and in traditional folk medicine is used for treating nausea, constipation and ulcers. ${ }^{2}$

Phytochemical investigations of asam kandis resulted in the isol tion of xanthones, ${ }^{3,4}$ benzophenones, ${ }^{5}$ dyhydrobenzopyran, ${ }^{6}$ acylphloroglucin$\mathrm{ol}^{7}{ }^{7}$ depsidone $\mathrm{e}^{8}$ and tetraprenyltoluquinone. ${ }^{9,10}$ Previous investigation on the stem bark of this plant revealed the presence of nine prenylated polyhydroxyxanthones as well as pyrano-xanthones. ${ }^{11}$ The organic acid content in fresh leaves, fruits and dried rinds of asam kandis had been investigated and found that (-) hydroxycitric acid and its lactone constitute the major constituents. ${ }^{12}$ Previous investigation of the stembark of asam kandis revealed the presence of 6-hydroxy- calabaxanthone, 2-(3-methyl-2-butenyl)-1,5,6-trihydroxy-3-methoxy-4-(1,1-dimethyl-2-propenyl)-9H-xanthen-9-one, rubraxanthone, a-mangostin, a new compound 1,3,6-trihydoxy-7-methoxy-4-(4-acetoxy-3-methyl-2butenyl)-8-(3,7-dimethyl-2,6-octadienyl) xanthone and cowanin. a-mangostin and cowanin were found to be potent against MCF-7 while 6-hydroxy-calabaxanthone potent against DU-145 cell lines. ${ }^{3}$

In continuating of our studies on asam kandis ( G. cowa), ${ }^{3,8}$ we further investigated the cytotoxicity of the leaves of this species on T47D breast cancer cells line.

\section{MATERIALS AND METHODS}

\section{Plant materials and extraction}

The leaves of G. cowa were collected in Padang. The plant material was air dried in the green house for 3 days at room temperature, followed by oven drying at $40^{\circ} \mathrm{C}$ for one day. The dry leaves were grinded to powder form using a laboratory blender. The powdered sample was kept in an airtight container until required. About $2 \mathrm{~kg}$ of the powdered the leaves of $G$. cowa was macerated in $15 \mathrm{~L}$ of ethanol $70 \%$ for 3 days. This process was repeated 3 times. Rotary evaporator was used to evaporate and concentrated ethanol extract at $40^{\circ} \mathrm{C}$. The resulting extract was kept in the refrigerator.

\section{Methods}

All procedures were described in our previous study. ${ }^{13}$ 
Table 1 : Percentage Viability of cells on each plate

\begin{tabular}{ccccc}
\hline \multicolumn{4}{c}{ Concentration } \\
\hline Plate & $0.1 \mu \mathrm{g} / \mathrm{mL}$ & $1 \mu \mathrm{g} / \mathrm{mL}$ & $10 \mu \mathrm{g} / \mathrm{mL}$ & $100 \mu \mathrm{g} / \mathrm{mL}$ \\
$\mathbf{1}$ & $76.41 \%$ & $67.36 \%$ & $38.86 \%$ & $18.36 \%$ \\
$\mathbf{2}$ & $71.44 \%$ & $67.36 \%$ & $35.14 \%$ & $19.26 \%$ \\
$\mathbf{3}$ & $88.79 \%$ & $81.22 \%$ & $50.20 \%$ & $28.25 \%$ \\
\hline
\end{tabular}

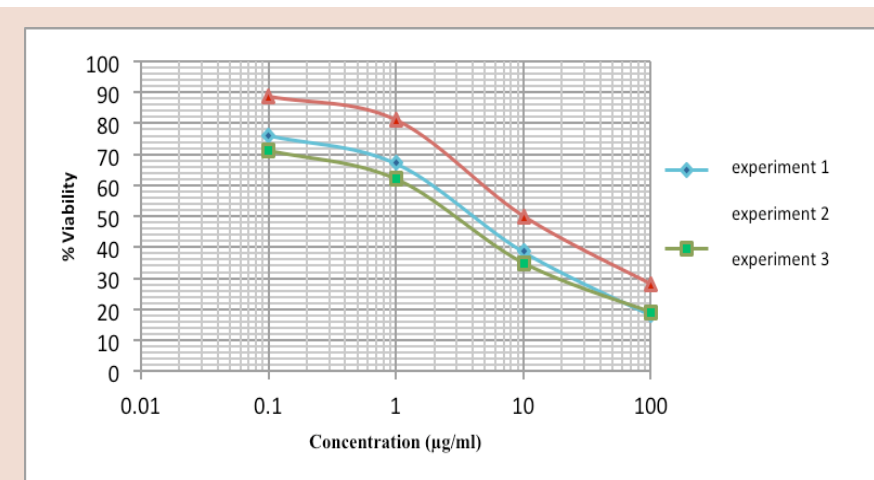

Figure 1: Dose-response relationship curve of the leaves extract of $G$. cowa against breast cancer T47D cells ( 24 Hours)

\section{RESULTS}

\section{Cytotoxic effect toward T47D}

The cytotoxicity effect of ethanol extract of leaves of asam kandis on T47D was evaluated by MTT assay. The extract from asam kandis in multiple concentrations was used. The effective concentration was calculated from concentration-response curve. The percentage of viability of each plate was shown in Table 1 .

Based on the MTT assay (Figure 1), it was found that the ethanol extract of the leaves of asam kandis had $\mathrm{IC}_{50}$ value of $6.13 \pm 3.51 \mu \mathrm{g} /$ $\mathrm{mL}$. The criteria of cytotoxicity for the crude extract, as established by the U.S. National Cancer Institute (NCI), are an $\mathrm{IC}_{50}<20 \mu \mathrm{g} / \mathrm{mL}$ in the preliminary assay. ${ }^{14}$

\section{Evaluation on morphological changes upon treatment with extracts}

The difference in concentration gives a different picture when viewed with a microscope inverted when compared to control. Figure 2 showed that many cancer cells grow and attached at the base of the flask at a concentration of $0.1 \mu \mathrm{g} / \mathrm{mL}$ and $1 \mu \mathrm{g} / \mathrm{mL}$. Cells grow very dense and very little distance between one cell to another cell so it almost looks no difference with control. While at a concentration of $10 \mu \mathrm{g} / \mathrm{mL}$, the cells look less than the concentration of $0.1 \mu \mathrm{g} / \mathrm{mL}$ and $1 \mu \mathrm{g} / \mathrm{mL}$. Cells are visible only in small groups so that the distance a group of cells with other cells look far. It is also evident from the low absorbance value. Another case in a concentration of $100 \mu \mathrm{g} / \mathrm{mL}$, the cells look less, there is no longer even visible cell growth. Dead cells will not be visible cell nucleus (white) and opaque. Absorbance also suggests that little living cells.

\section{DISCUSSION}

MTT assay is a colorimetric cytotoxic test method to determine the number of living cells based on changes in a solution of 3-(4,5-dimetilthiazol-2-il)-2,5-difeniltetrazolium bromide were colored yellow to purple formazan crystals by active mitochondria in living cells. MTT is absorbed into living cells and broken through the oxidation reaction by nicotinamide adenine dinucleotide $\left(\mathrm{NAD}^{+}\right)$as enzyme in the mitochondrial respiratory chain into formazan that was not soluble in water.

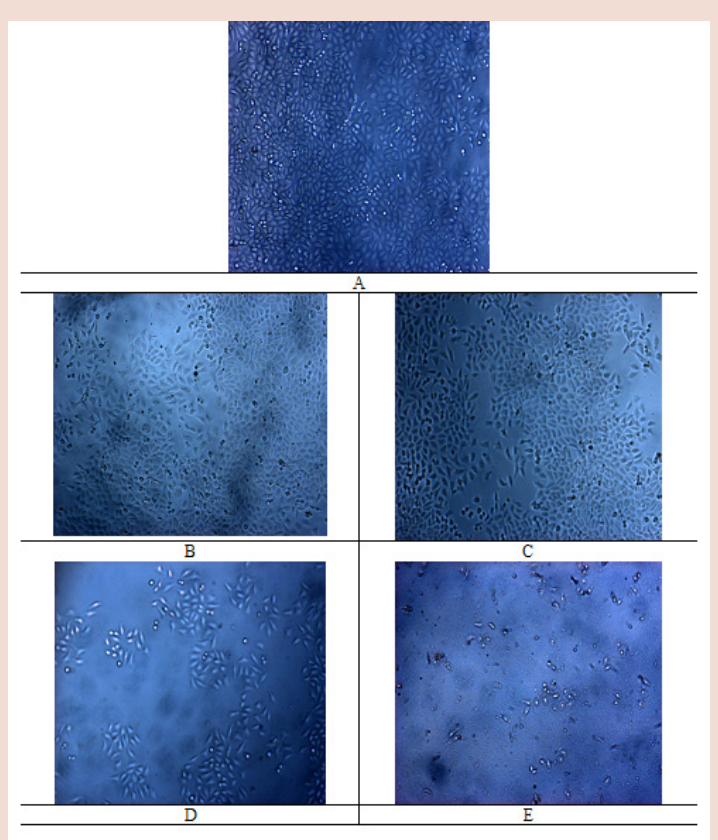

Figure 2: Morphological changes of the T47D cells with out treatment/control (A), after treated with $0.1 \mu \mathrm{g} / \mathrm{mL}$ (B), $1 \mu \mathrm{g} / \mathrm{mL}$ (C), $10 \mu \mathrm{g} / \mathrm{mL}$ (D) and $100 \mu \mathrm{g} / \mathrm{mL}$ (E) ethanol extract of $G$. cowa for 24 hours. (100x enlargement)

Purple color intensity is directly proportional to the amount of the active cell metabolism. Formed the darker color, the higher the absorbance value, and the more living cells. ${ }^{15}$

Breast cancer cell used in this research was T47D cell. T47D breast cancer cell is sensitive to chemotherapeutic agents and have a fast replication capability that is well suited for the cytotoxic test. The multiple concentrations of ethanol extract from asam kandis were used and effective concentration was calculated from concentration-response curve. The results of the cytotoxicity evaluation against T47D cell lines of the kandis extract were shown in Figure 1. The ethanol extract of the leaves of asam kandis exhibited significant activity against T47D cell lines with $\mathrm{IC}_{50} 6.13 \pm 3.51 \mu \mathrm{g} / \mathrm{mL}$.

Data processing using One Way ANOVA followed by Duncan Advanced Test. Results of One Way ANOVA test $(\alpha=0.05)$ suggesting that the leaves extract asam kandis gave significantly different barriers to the growth of T47D breast cancer cells. The results obtained on a One Way ANOVA test were significantly different, then followed by Duncan test at $5 \%$ significance level (Table 1). Duncan further test the data obtained that the concentration of $100 \mu \mathrm{g} / \mathrm{mL}$ significantly different from the concentration of $10 \mu \mathrm{g} / \mathrm{mL}$, a concentration of $10 \mu \mathrm{g} / \mathrm{mL}$ significantly different from the concentration of $1 \mu \mathrm{g} / \mathrm{mL}$. However the concentration of $1 \mu \mathrm{g} /$ $\mathrm{mL}$ and $0.1 \mu \mathrm{g} / \mathrm{mL}$ was not significantly different.

Based on the relationship curve between the concentration of the test compound with the $\%$ cell viability can be observed that the leaves of asam 
kandis extract at a concentration of $0.1 \mu \mathrm{g} / \mathrm{mL}$ and $1 \mu \mathrm{g} / \mathrm{mL}$ did not affect the amount of reduction in the number of cells that survive, but at higher concentrations i.e. at a concentration of $10 \mu \mathrm{g} / \mathrm{mL}$ and $100 \mu \mathrm{g} / \mathrm{mL}$ can be observed a decrease in \% cell viability, significantly. Based on the statistical results, it can be concluded that the average percentage of cell viability at a concentration test showed a highly significant difference $(\mathrm{p}<0.01)$.

\section{CONCLUSION}

The results of this research suggest that ethanol extract of the leaves of asam kandis was potential source of herbal medicine for cancer-related ailments.

\section{ACKNOWLEDGEMENT}

This work was supported by Faculty of Pharmacy, Andalas University.

\section{CONFLIC OF INTEREST}

Authors do not have any conflict of interest.

\section{REFERENCES}

1. WHO. Diet, Nutrition and the Prevention of Chronic Diseases. World Health Organization, Technical Report Series Geneva; 2013. 916.

2. Lim TK. Edible Medicinal and Non-Medicinal Plants. Fruits, Springer Science and Business Media B.V., London 2012; 2(1): 29-34.

3. Wahyuni FS, Shaari K, Stanslas J, Lajis NH, Dachriyanus. Cytotoxic xanthones from the stem bark of Garcinia cowa Roxb. J Chem and Pharm Res. 2015; 7(1): $227-23$
4. Wahyuni FS, Shaari K, Stanslas J, Lajis NH, Hamidi D. Cytotoxic compounds from the leaves of Garcinia cowa Roxb. J Appl Pharm Sci. 2015 5(02): 006-11.

5. Trisuwan K, Ritthiwigrom T. Benzophenone and Xanthone Derivatives from the Inflorescent of Garcinia cowa. Arch Pharm Res. 2012; 35(10): 1733-8.

6. Siridechakorn I, Phakhodee W, Ritthiwigrom T, Promgool T, Deachathai S, Cheenpracha S, et al. Antibacterial dihydrobenzopyran and xanthone derivatives from Garcinia cowa stem barks. Fitoterapia 2012; 83(8):1430-4.

7. Xu G, Kan WL T, Zhou Y, Song JZ, Han QB, Qiao CF. Cytotoxic acylphloroglucinol derivatives from the twigs of Garcinia cowa. J Nat Prod. 2010; 73(2): 104-8.

8. Cheenpracha S, Phakhodee W, Ritthiwigrom T, Prawat U, Laphookhieo S. A new depsidone from the twigs of Garcinia cowa. Heterocycles 2011; 83(1): 1139-44.

9. Wahyuni FS, Byrne LT, Dachriyanus Dianita $\mathrm{R}$, Lajis NH, Sargent MV et al. A New ring-reduced tetraprenyltoluquinone and a prenylated xanthone from Gar cinia cowa. Aust J Chem. 2004; 57(3): 2263-6.

10. Wahyuni FS, Stanslas J, Lajis NH, Hamidi D. Cytotoxicity studies of tetraprenyltoluquinone, a prenylated hydroquinone from Garcinia cowa. Int J Pharm Pharm Sci. 2015; 7(3): 60-3.

11. Shen J, Yang JS. Two new xanthones from the stems of Garcinia cowa. Chem Pharm Bull. 2006; 54(1): 126-8.

12. Jena BS, Javaprakasha GK, Sakariah KK. Organic Acid from leaves fruit, and rinds of Garcinia cowa. J Agric Food Chem. 2002; 50(12): 3431-4

13. Husni E, Nahari F, Wirasti Y, Wahyuni FS, Dachriyanus. Cytotoxicity study of ethanol extract of the stem bark of asam kandis (Garcinia cowa Roxb.) on T47D breast cancer cell line. Asian Pac J Trop Biomed. 2015; 5(3): 249-52.

14. Kuete V, Ango PY, Yeboah SO, Mbaveng AT, Mapitse R, Kapche GD WF, et al. Antiproliferative activity and induction of apoptosis by Annona muricata ( $A n-$ nonaceae) extract on human cancer cells. BMC Complem Altern M. 2014 14(1): 340.

15. Mosmann T. Rapid Colorimetric Assay for Cellular Growth and Survival: Application to proliferation and cytotoxicity Assays. J. Immunol. Methods 1983; 65: 55-63.

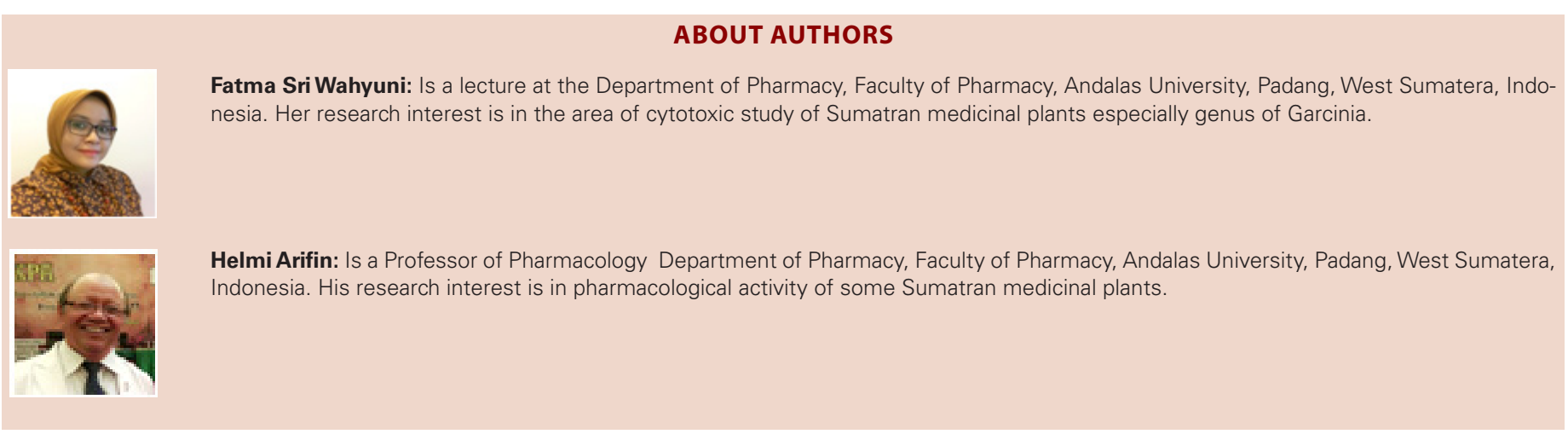

